\title{
ECONOMIC STATUS OF THE RUSSIAN MINORITY IN TAJIKISTAN
}

\author{
Aijaz A. Bandey, Professor \\ Farooq Ahmad Rather, Research Scholar \\ Centre of Central Asian Studies, University of Kashmir, India \\ E-mail: draijazbandey@yahoo.co.in, faroogarather@yahoo.com
}

\begin{abstract}
From the 1980s onwards, there was a sharp economic decline in the entire Soviet Union including Central Asia. People in general were affected due to this economic decline; however, in case of the Slav minority in Central Asia including Tajikistan the outmigration of Russian, which started from the 1980s, affected them more than that of their Central Asian counterparts. After the disintegration of Soviet Union, the condition of the leftovers was further accentuated by the language policy, ethnicisation while recruitment in the public offices, etc. Besides this Tajikistan has been the poorest country in the post Soviet space, which in turn is adding to the economic hardships of the people in general and ethnic Russians of the country in particular.
\end{abstract}

\section{KEY WORDS}

Russian; Central Asia; Tajikistan; Migration; Jobs; Employment; Economy; Government; Representation.

The 1980s Soviet time sharp economic decline continued in the post 1991 era as well. ${ }^{1}$ Among the five republics of Central Asia Tajikistan is the poorest ${ }^{2}$ with lowest per capita GDP (\$6.3 billion for the year 2011). ${ }^{3}$

In this paper an attempt has been made to highlight the dwindling role of Russian ethnic minority in various economic sectors including state and administration of Tajikistan.

The non-indigenous populations of Central Asia (mostly Russians) were the bearers of the elite jobs in modern industry and services. ${ }^{4}$ They were the people who enabled modern sectors of economy to function. ${ }^{5}$ But the disintegration of USSR, Civil War and the changing socio-economic situation has brought sea-changes among the Russians employed in different branches of the industry and services. For one those who stayed back are insignificantly very low in number to manage the jobs held earlier by them. Secondly because of national language policy shift they have become aloof from important sectors like public health, education, culture, administrative work, and the professions like that of teachers, lawyers, writers, journalists, etc. ${ }^{6}$

Until 1991 Russians held the primary positions in every sector of power. They

1 The reasons for this included the withdrawal of subsidies from Moscow, the breakdown of inter-republic trade and the impact of government stabilisation policies; Serdar Savas, Gülin Gedik and Marian Craig, "The reform process", Health Care in Central Asia, Open University Press, Buckingham, Philadelphia, 2002, p. 80.

2 Ghafur Khodjamurodov and Bernd Rechel, Systems in Transition, Vol. 12, No. 2., Bernd Rechel (Ed.) and Martin McKee (Series Ed.), European Observatory on Health Systems and Policies, Denmark, 2010, p. 4; The industry and construction in Tajikistan in 1991 employed $21 \%$ of the general employed in economics population which came down to $9.1 \%$ in 2000; transport and communication in 1991 employed $5 \%$ which in 2000 , employed only $2.4 \%$ in 1991 ; and in other branches of goods production the number decreased from $2 \%$ in 1991 to $0.6 \%$ in 2000; T. N. Bozrikova, "Problems of Ethnic Minorities in Tajikistan", in Sub-regional Seminar on Minority Rights: Cultural Diversity and Development in Central Asia, p. 26.

3 Iraj Bashiri, Tajikistan: An Overview, 2003. Available online at www.angelfire.com.

4 Boris Rumer (Ed), Central Asia in Transition: Dilemmas of Political and Economic development, Aakar Books, India, 2003, p. 113.

5 Boris Rumer (Ed), Central Asia in Transition: Dilemmas of Political and Economic development, p. 117.

6 This exclusion of ethnic Russians from various posts was primarily due to their insufficient knowledge of local languages; Valerii Aleksandrovich Tishkov, Ethnicity, Nationalism and Conflict in and After the Soviet Union: The Mind Aflame, Sage Publications, Inc., Oslo, 1997, p. 123. 
constituted a significant share in the total population $\left(388,481\right.$ in 1988) ${ }^{7}$ thereafter they started to leave the country. In 1993 alone more than 200,000 or $51 \%$ left Tajikistan. ${ }^{8}$ So much so that in year 2000 there was only 68,000 Russians left in the country. ${ }^{9}$ Those leftovers belonged to either mixed families on account of intermarriages ${ }^{10}$ or had no means to leave. ${ }^{11}$

Today most of the left-over Russians regard Tajikistan their motherland mainly because they were born there or else lived in the country for decades ${ }^{12}$ but most of them are not at par with Tajiks as far as their political or economical wellbeing is concerned. In this paper we will try to assess their role in various economic sectors of the country. In addition to it we will try to discuss the reasons for their present situation.

After the 1917 Revolution and the subsequent formation of Soviet Union the migration pattern, even though continued, changed to the extent of coming of professionals in Central Asia. This was primarily because Soviet Union followed socialism and new economic policies thereof encouraged migrations of all peoples from their homeland to their place of working. The influx of Russians assumed an organized character during these years after the beginning of industrialisation in Central Asia as an influx of immigrant Russians grew rapidly ${ }^{13}$ which is what has been reflected in the following table.

Table 1. Populations in Kazakhstan (1926-89)

\begin{tabular}{|c|c|c|c|c|c|c|}
\hline & \multicolumn{2}{|c|}{1926} & \multicolumn{2}{|c|}{1959} & \multicolumn{2}{|c|}{1989} \\
\hline & Total no. & $\%$ & Total no. & $\%$ & Total no. & $\%$ \\
\hline All population & 6229.9 & 100.0 & 9294.7 & 100.0 & 16464.5 & 100.0 \\
\hline Kazakhs & 3627.6 & 58.2 & 2787.3 & 30.0 & 6534.6 & 39.7 \\
\hline Russians & 1274.0 & 20.5 & 3972.0 & 42.7 & 6227.5 & 37.8 \\
\hline Úkrainians & 860.2 & 13.8 & 761.4 & 8.2 & 957.5 & 5.8 \\
\hline Germans & 58.7 & 0.9 & 659.7 & 7.1 & 957.5 & 5.8 \\
\hline Others & 408.5 & 6.6 & 1114.3 & 12.0 & 1848.7 & 11.2 \\
\hline
\end{tabular}

Source: K. Nurpeis, "Kazakhstan”, History of Civilizations of Central Asia, Vol. VI, p. 254.

What is understood from the above table has been that by the year 1959 the Russian and other migrants had outnumbered the natives in Kazakhstan; and majority was of the Russians ${ }^{14}$ (almost $40 \%$ of the total population). ${ }^{15}$ In 1959 census, Kazakhstan was home to $4,014,000$ Russians and 762,000 Ukrainians, who together made up $51 \%$ of its total population. ${ }^{16}$ In the northern Kazakhstan the Russians were mainly peasants, while as in

7 Tajikistan Country Profile, Central Asia Executive Summary Series, Programme for Culture and Conflict Studies (CCS) Department of National Security Affairs Naval Postgraduate School No. 3, California, July 2009, P. 7.

8 Sebastien Peyrouse, "The Russian Minority in Central Asia: Migration, Politics and Language", Occasional Papers, Woodrow Wilson International Center for Scholars, Washington, D.C., 2008, p. 6.

$9 \quad$ Sebastien Peyrouse, Occasional Papers, p. 6.

10 T. N. Bozrikova, "Problems of Ethnic Minorities in Tajikistan", a Sub-regional Seminar on Minority Rights: Cultural Diversity and Development in Central Asia, pp. 21-22.

11 Charles King and Neil J. Melvin, "Diaspora Politics: Ethnic Linkages, Foreign Policy, and Security in Eurasia", International Security, Vol. XXIV, No. III, p. 123, available online at http://belfercenter.hks.harvard.edu/publication/438/diaspora_politics.html, accessed 04 April 2012.

12 T. N. Bozrikova, "Problems of Ethnic Minorities in Tajikistan", a Sub-regional Seminar on Minority Rights: Cultural Diversity and Development in Central Asia, pp. 38-39

13 Stefani Hoffman, "Russia's Diasporas: The Case of the Russian-speaking Community in Israel", Working Paper Series on Russia and the Former Soviet States, Liechtenstein Institute on Self-Determination at Princeton University, United States, August 2003.

14 During 1950s and 1960s some Russian settlers came in connection with some economic projects like the 'Virgin Land Campaign' (particularly in Kazakhstan), or natural disasters like the reconstruction of Tashkent after the earthquake of 1966.

15 K. Nurpeis, "Kazakhstan", History of Civilizations of Central Asia, Vol. VI, Chahryar Adle (President), UNESCO, Paris, 2005, p. 254.

16 Ian Murray Matley, Central Asia: A Century of Russian Rule, p. 108. 
other parts in Central Asia they settled down mainly in urban and industrial centers. ${ }^{17}$ Samarqand contained 11,650 Russians out of its total population of 80,700 in $1908^{18}$, which rose to 23,000 by 1910; Fergana (developed as an industrial centre by the Russians) contained 11,000 Russians (70\% of the total population) in 1911; Syr Darya had a big lot of 101,289 Russian settlers in $1910^{19}$; in 1911 there were 8,000 Russians in Frunze modern Bishkek (when its total population was 14,000). ${ }^{20}$

Kyrgyzstan, like other Central Asian republics, also saw increase of Russian migrants as in 1926 their number reached to $180,000 .^{21}$ Between 1926 and 1939 their number increased to $366,000^{22}$ which further grew by $1950-60$ as the Russians and Ukrainians togather made up one third of the country's population. ${ }^{23}$ Following table amply provides the population format represented by major ethnic groups from 1926 to 1989.

Table 2. \%age Ethnic structure in the Kyrgyz SSR (1926-89)

\begin{tabular}{|c|c|c|c|c|c|}
\hline $\mathrm{n} / \mathrm{n}$ & 1926 & 1939 & 1959 & 1979 & 1989 \\
\hline Kyrgyz & 66.7 & 51.7 & 40.5 & 47.9 & 52.4 \\
\hline Uzbeks & 11.1 & 10.3 & 10.5 & 12.1 & 12.9 \\
\hline Russians & 11.7 & 20.8 & 30.2 & 25.9 & 21.5 \\
\hline Ükrainians & - & 9.4 & 6.6 & 3.1 & 2.5 \\
\hline
\end{tabular}

Source: A. Tabyshalieva, "Kyrgyzstan", History of Civilizations of Central Asia, Vol. VI, p. 275.

The modern Uzbekistan saw the migration of Slaves from 1880s. ${ }^{24}$ Since Tashkent, under Tsars, was the seat of administration of Turkestan to attract a large section of Russians who in 1911 were 202,000 (4\%) in a population of $5,090,000^{25}$ and by 1926 their number reached to $269,000 .{ }^{26}$ In a short period of just five years, between 1933 to 1938 , about 650,000 Russian migrants came to the republic to settle down mostly in the towns. ${ }^{27}$ By 1959 there were some 1,101,000 Russians and together with 88,000 Ukrainians they comprised $51 \%$ of its population. ${ }^{28}$ In 1989 , there were as many as 1.8 million Russians in Uzbekistan. ${ }^{29}$

17 Elizabeth E. Bacon, Central Asians Under Soviet Rule: A Study in Culture Change, Cornell University Press, Ithaca and London, 1966, p. 26.

18 In the Khanates of Bukhara and Khiva, the number of Russians was scarce; Elizabeth E. Bacon, Central Asians Under Soviet Rule: A Study in Culture Change, p.106. In 1897 Bukhara had 28,200 Russian settlers, about $1 \%$ of the total population of 3,000,000; Lawrence Krader, Peoples of Central Asia, Indiana University, Bloomington, Indiana, 1963, p.175. The number of Russians in Bukhara and Khiva had increased from 12,000 in 1897 to 50,000 in 1917 . These Russian settlers in Bukhara and Khiva were only military personnel; Lawrence Krader, Peoples of Central Asia, p. 179.

19 Ian Murray Matley, Central Asia: A Century of Russian Rule, p.105. The aggregate Russian population of the regions of Syr Darya, Fergana, Samarkand and Transcaspia in 1910 was 202,290 out of its total population of 5,291,152; Elizabeth E. Bacon, Central Asians Under Soviet Rule: A Study in Culture Change, p. 106.

20 Ian Murray Matley, Central Asia: A Century of Russian Rule, p. 105.

21 Lawrence Krader, Peoples of Central Asia, p. 183.

22 Lawrence Krader, Peoples of Central Asia, p. 187.

23 A. Tabyshalieva, "Kyrgyzstan", History of Civilizations of Central Asia, Vol. VI, Chahryar Adle (President), UNESCO, Paris, 2005, p. 275. In the 1959 census Kyrgyzstan had 624,000 Russians and 137,000 Ukrainians, that is $37 \%$ of its total population; lan Murray Matley, Central Asia: A Century of Russian Rule, p. 109.

24 International League for Human Rights, On the Compliance of the Republic of Uzbekistan with The United Nations Convention on Elimination of All Forms of Racial Discrimination, 68th Session of the UN Committee on the Elimination of Racial Discrimination (UN CERD), New York, February 20 - March 10, 2006, P. 8.

25 Among these 4\% (202,000), 177,374 represent the urban population leaving only 25,000 rural people in the entire region; Gavin Hambly et al, Central Asia, p. 219.

26 Lawrence Krader, Peoples of Central Asia, p. 183.

27 D. A. Alimova and A. A. Golovanov, "Uzbekistan", Chahryar Adle (President), History of Civilizations of Central Asia, Vol. VI, UNESCO, Paris, 2005, p. 226.

28 lan Murray Matley, Central Asia: A Century of Russian Rule, p. 109.

29 International League for Human Rights, On the Compliance of the Republic of Uzbekistan with The United Nations Convention on Elimination of All Forms of Racial Discrimination, 68th Session of the UN Committee on the Elimination of Racial Discrimination (UN CERD), New York, February 20 - March 10, 2006, P.8; 
The case of modern Tajikistan was not different in respect of receiving the Russian migrants. Since before Soviet formation there was overlapping in the geographical and political boundaries of Uzbekistan and Tajikistan therefore the exact figures of migrants is not strictly reliable. However by 1926 Russians settled there were hardly few; in fact just 5600 were living in towns. ${ }^{30}$ From hereafter they rose to 127,000 by $1939^{31}$ increasing almost about 25 times in a period of just 13 years. The trend continued thereafter as well, as is depicted in the following table.

Table 3. Demographic Development of Tajikistan during Soviet Rule

\begin{tabular}{|c|c|c|c|c|c|c|c|c|c|c|c|c|}
\hline \multirow[b]{2}{*}{$\begin{array}{l}\text { Ethnic } \\
\text { Group }\end{array}$} & \multicolumn{2}{|c|}{1926} & \multicolumn{2}{|c|}{1929} & \multicolumn{2}{|c|}{1939} & \multicolumn{2}{|c|}{1959} & \multicolumn{2}{|c|}{1979} & \multicolumn{2}{|c|}{1989} \\
\hline & $\begin{array}{l}\text { No. in } \\
\text { Th }\end{array}$ & $\%$ & $\begin{array}{l}\text { No. in } \\
\text { Th }\end{array}$ & $\%$ & $\begin{array}{l}\text { No. in } \\
\text { Th }\end{array}$ & $\%$ & $\begin{array}{l}\text { No. in } \\
\text { Th }\end{array}$ & $\%$ & $\begin{array}{l}\text { No. in } \\
\text { Th }\end{array}$ & $\%$ & $\begin{array}{l}\text { No. in } \\
\text { Th }\end{array}$ & $\%$ \\
\hline Tajik & 620.0 & 75 & 901.4 & 78.4 & 883.6 & 59.5 & $1,051.2$ & 53.1 & $2,237.5$ & 58.8 & $3,172.4$ & 62.3 \\
\hline Uzbek & - & - & 206.3 & 17.9 & 353.6 & 23.8 & 454.4 & 23.0 & 873.2 & 22.9 & $1,197.8$ & 23.5 \\
\hline Russian & 56 & & & & & 103 & 262.6 & 13.3 & 395.1 & 10.4 & 388.5 & 7.6 \\
\hline Úkrainian & 5.6 & 0.1 & - & - & 153 & 10.3 & 26.9 & 1.4 & 35.8 & 0.9 & 41.4 & 0.8 \\
\hline Kyrgyz & & 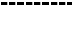 & २ & ? & & & 25.6 & 1.3 & 48.4 & 1.3 & 63.8 & 1.3 \\
\hline Kazakh & - & - & 22.8 & 2.0 & - & - & 12.6 & 0.6 & - & - & 11.4 & 0.2 \\
\hline Turkmen & - & - & 16.4 & 1.4 & - & - & 7.1 & 0.4 & 14.0 & 0.4 & 20.5 & 0.4 \\
\hline Tatar & - & - & - & - & - & - & 56.9 & 2.9 & 79.5 & 2.1 & 72.2 & 1.4 \\
\hline German & - & - & - & - & - & - & 32.6 & 1.6 & 38.9 & 1.0 & 32.7 & 0.6 \\
\hline Jew & - & - & - & - & - & - & 12.4 & 0.6 & 14.7 & 0.4 & 14.8 & 0.3 \\
\hline Korean & - & - & - & - & - & - & - & - & - & - & 13.4 & 0.3 \\
\hline other & 406.4 & 24.3 & - & - & 94.9 & 6 & 37.6 & 1.9 & 69.6 & 1.8 & 63.4 & 1.2 \\
\hline Total & 1,032 & - & - & - & $1,485.1$ & - & $1,979.9$ & - & $3,806.2$ & - & $5,092.6$ & - \\
\hline
\end{tabular}

Compiled on the basis of: U.S.S.R Census 1939,1959,1979,1989, Tereska Rakowska-Harmston 1971 and calculations made by Aaron Erlich in his "Tajikistan: From Refugee Sender to Labor Exporter", Migration Policy Institute, July 2006, accessed 04 September 2012.

The trend and pattern of Russian migration in any of the five Central Asian republics started to decline as the census of 1979 has shown. The disintegration of the USSR and the exit of Russians from these independent states further declined their numbers in Central Asia as the case of Tajikistan represents in the following table.

Table 4. Population of ethnic Russians in Tajikistan from 1989 to 2000

\begin{tabular}{|c|c|c|c|c|}
\hline Nationality & Total Population & Percent Change & Percent of Total Population \\
\hline Russian & 1989 & 2000 & $1989-2000$ & 1989 \\
\hline
\end{tabular}

Source: Tajikistan Country Profile, Central Asia Executive Summary Series, Programme for Culture and Conflict Studies (CCS) Department of National Security Affairs Naval Postgraduate School No. 3, California, July 2009, P.7.

The incremental growth of Russian migrations continued after the formation of USSR between 1926 to $1939^{32}$ more than 1.7 million Russians left European Russia to live in Central Asia ${ }^{33}$ taking their lot to $3,866,000(23 \%)$ in $1939^{34}$ and to $6,265,000$ in $1959 .^{35}$ During World War II, many industrial enterprises and academic institutions were shifted to

Political Conditions in the Post-Soviet Era, Profile Series: Uzbekistan, Ins Resource Information Center, Washington, D.C., September 1994, p. 7.

30 Aaron Erlich, Tajikistan: From Refugee Sender to Labor Exporter, Migration Policy Institute, July 2006, available online at http://www.migrationinformation.org/Profiles/display.cfm?ID=411

31 Lawrence Krader, Peoples of Central Asia, p. 187.

32 Those Russian migrants who came to Central Asia during the period of World War II got settled in the urban areas like Dushanbe (Stalinabad), Frunze (Pishpek), and other regions; lan Murray Matley, Central Asia: $A$ Century of Russian Rule, p. 95.

33 Sebastien Peyrouse, Occasional Papers, p. 2.

34 Lawrence Krader, Peoples of Central Asia, p. 187.

35 Lawrence Krader, Peoples of Central Asia, p. 193. 
the east of Ural Mountains, which carried with them another wave of immigrants to Central Asia. Yet another lot of hundreds of thousands of the 'punished people' among others who were accused of collaboration with the enemy were altogether deported to Central Asia. ${ }^{36}$ Following table shows the presence of Russians in Central Asian republics from $1959^{37}$ onwards wherein their number started to dwindle from 1970 - a trend that further shows decrease after the disintegration of the Soviet Union.

Table 5. Number of Russians (and their percentage of the total population) in each Central Asian Republic

\begin{tabular}{|c|c|c|c|c|c|c|}
\hline$n / n$ & 1959 & 1970 & 1979 & 1989 & 1999-2000 & $\begin{array}{c}2007 \\
\text { Estimates }\end{array}$ \\
\hline Kazakhstan & $\begin{array}{c}3,974,000 \\
(42.7 \%)\end{array}$ & $\begin{array}{c}5,521,000 \\
(42.4 \%)\end{array}$ & $\begin{array}{c}5,991,000 \\
(40.8 \%)\end{array}$ & $\begin{array}{c}6,227,000 \\
(37 \%)\end{array}$ & $\begin{array}{c}4,479,000 \\
(30 \%)\end{array}$ & $\begin{array}{c}\text { Approx. } \\
4,000,000\end{array}$ \\
\hline Kyrgyzstan & $\begin{array}{l}623,500 \\
(30.2 \%)\end{array}$ & $\begin{array}{l}856,000 \\
(29.2 \%)\end{array}$ & $\begin{array}{l}911,700 \\
(25.9 \%)\end{array}$ & $\begin{array}{l}916,500 \\
(21.5 \%)\end{array}$ & $\begin{array}{l}603,000 \\
(12.5 \%)\end{array}$ & $\begin{array}{l}\text { Approx. } \\
500,000\end{array}$ \\
\hline Uzbekistan & $\begin{array}{c}1,100,000 \\
(13.5 \%)\end{array}$ & $\begin{array}{c}1,473,000 \\
(12.5 \%)\end{array}$ & $\begin{array}{c}1,665,000 \\
(10.8 \%)\end{array}$ & $\begin{array}{c}1,653,000 \\
(8.3 \%)\end{array}$ & $\begin{array}{c}\text { Approx. } \\
900,000 \\
(3 \%)\end{array}$ & $\begin{array}{l}\text { Approx. } \\
800,000\end{array}$ \\
\hline Tajikistan & $\begin{array}{l}262,600 \\
(13.3 \%)\end{array}$ & $\begin{array}{r}344,000 \\
(11.8 \%)\end{array}$ & $\begin{array}{l}395,000 \\
(10.4 \%)\end{array}$ & $\begin{array}{c}388,500 \\
(7.6 \%)\end{array}$ & $\begin{array}{c}68,000 \\
(1 \%)\end{array}$ & $\begin{array}{l}\text { Approx. } \\
50,000\end{array}$ \\
\hline Turkmenistan & $\begin{array}{l}262,700 \\
(17.3 \%)\end{array}$ & $\begin{array}{l}313,000 \\
(14.5 \%)\end{array}$ & $\begin{array}{l}349,000 \\
(12.6 \%)\end{array}$ & $\begin{array}{c}334,000 \\
(9.5 \%)\end{array}$ & $\begin{array}{c}\text { Approx. } \\
120,000 \\
(2 \%)\end{array}$ & $\begin{array}{c}\text { Less than } \\
150,000\end{array}$ \\
\hline
\end{tabular}

Source: Sebastien Peyrouse, "The Russian Minority in Central Asia: Migration, Politics and Language", Ocasional Papers, p. 4.

Soviets nationalised all means of production like agricultural land and industry (including small scale, tiny cottage units and business establishments) and all other resources including mineral resources, transport and communication, etc. ${ }^{38}$ therefore, to implement a new socio-economic order many major policies and decisions were taken. One of these was implementing the Five Year Plans to organize trained and educated human resource. This called to set up large number of industries and placed nearer to the sources of raw material. ${ }^{39}$ As a result, not only the industrial output increased tremendously but also a large number of industrial class of workers were employed wherein a large number of Russians, besides other Slaves, migrated to Central Asia to be employed in these industries. ${ }^{40}$ The major reason for their employment was that almost all natives were unskilled to run the newly established factories, even though the government, side by side, also spread education, elementary and vocational, far and wide to produce skilled labour class for these industries. Yet because of the World War II, still more Russians entered Central Asia as a large number of industries were shifted there to protect these from War. Again in these industries major job market was for immigrant Russians. ${ }^{41}$

The Russians also brought medical knowledge and built hospitals, medical clinics and

36 Shirin Akiner, Health Care in Central Asia, p. 16.

37 The influx of Russian immigrants since 1960s was closely linked to the growth of urban centers like Tashkent, Bukhara, Samarkand, Andijan, Khokand, Fergana, etc; Ian Murray Matley, Central Asia: A Century of Russian Rule, pp. 102-103.

38 Imtiyaz ul Haq, "Economic Transition in Central Asian Republics: Problems and Prospects" Mushtaq A. Kaw (Ed), Central Asia: Continuity and Change, Centre of Central Asian Studies, University of Kashmir, Srinagar, India, 1999, p. 55.

39 W. P. and Zelda K. Coats, Soviets in Central Asia, Lawrence and Wishart Ltd., London, 1951, p. 109.

40 The immigrant Russian workforce in Central Asia continued to dominated the industrial, technical, educational and medical care sectors until the end of the 1950s; Saltanat Sulaimanova, "Migration Trends in Central Asia: The Case of Trafficking of Women", Daniel L. Burghart and Theresa Sabonis-Helf (Eds), In the Tracks of Tamerlane: Central Asia's Path to the $21^{\text {st }}$ Century, National Defense University Press, Canada, 2004, pp. 377-378.

41 Shirin Akiner, "History and Politics in Central Asia", Health care in Central Asia, Martin McKee, Judith Healy and Jane Falkingham (Eds), Open University Press, Buckingham, Philadelphia, 2002, p. 16. 
pharmacies. ${ }^{42}$ Initially, under Tsars, the health system in Central Asia started on a very modest scale mainly to take care of the Russian military and administrative personnel. ${ }^{43}$ However, under Soviet rule the health care system in Central Asia was not only universalized ${ }^{44}$ but a modern health care system was developed. ${ }^{45}$ Soviet government sent many young graduates and professionals, mainly Russians, to work in Central Asia ${ }^{46}$ till Central Asians themselves attained medical degrees or a course trained by the Russians in preventive care such as generalists and nurse practitioners. ${ }^{47}$ Accordingly by 1961 Central Asia had 102 times as many doctors as in 1913 and the number of hospital beds had increased to $85,300 .^{48}$

Soviets also brought some drastic changes in the field of education in Central Asia. ${ }^{49}$ Initially the teaching experts were exclusively Russians; however, with the passage of time natives also joined them as teachers of modern education. Between 1917 and 1919 foundation of a new education policy was laid down in which education ${ }^{50}$ was made free and compulsory up to 17 years of age..$^{51}$ In 1920 many higher educational institutes like Tashkent University was established and in 1940s many scientific institutes and laboratories were setup. Such was the progress made in the field of education that the literacy rate among the native people of Central Asia reached to $99 \%$ by 1970 from a mere $1-2 \%$ in $1917 . .^{52}$

The data related the present scenario explains the position existing in the country. In January 2009 , out of the total of the 17,580 civil service administrative staff of the country, just $173(1 \%)$ were Russian ${ }^{53}$ and out of 99 supreme judicial authorities only one belongs to Russian ethnic minority. ${ }^{54}$ Similarly out of the 4,976 employed by the state ministries, 55 were Russian $^{55}$ and again out of the 780 civil servants employed by the state committees, 31 were Russians. ${ }^{56}$ Their small number in the country is also reflected by the share of Russians

42 Peter L. Roudik, The History of the Central Asian Republics, Library of Congress Cataloging-in-Publication Data, United States of America, 2007, p. 85.

43 A. K. Patnaik, "Education, the press and public health", Chahryar Adle (President), History of Civilizations of Central Asia, Vol. VI, UNESCO, Paris, 2005, p. 578.

44 Martin McKee, Judith Healy and Jane Falkingham, Health care in Central Asia, Open University Press, Buckingham, Philadelphia, 2002, p. 7.

45 A. K. Patnaik, "History of Civilizations of Central Asia, Vol. VI, p. 578.

46 Shirin Akiner, Health Care in Central Asia, p. 16; Steven L. Burg, "Russians, Natives and Jews in the Soviet Scientific Elite. Cadre Competition in Central Asia", Cahiers du Monde russe et soviétique, Vol. XX, No. I, Ehess, January - March, 1979, p. 49, accessed 01 February 2012.

47 Many doctors were trained only to address the needs of a specific sex or age group suffering from a specific disease, while nurses had limited skills and undertook only basic tasks. As an example of the extreme overspecialisation of Soviet health care, Kyrgyz obstetricians neither owned nor knew how to use stethoscopes; Saltanat Sulaimanova, In the Tracks of Tamerlane: Central Asia's Path to the $21^{\text {st }}$ Century, p. 224.

48 A. K. Patnaik, History of Civilizations of Central Asia, Vol. VI, p. 580.

49 The introduction of a new alphabet based on Russian script played an important role in the development of education for it proved instrumental in indigenous group's homogenisation in education not only in Central Asia but in the entire USSR; Mohammad Monir Alam, Russia and Tajikistan: Political and Security Relationship, Lancer Books, New Delhi, 2011, p. 60.

50 The spread of mass education was prioritized because it was important for political, economic, and social reasons; Shirin Akiner, Health Care in Central Asia, p.15

51 A. K. Patnaik, History of Civilizations of Central Asia, Vol. VI, p. 552.

52 A. K. Patnaik, History of Civilizations of Central Asia, Vol. VI, p. 550-553; W. P. and Zelda K. Coats, Soviets in Central Asia, p. 112.

53 Whereas 14,625 (88.3\%) were Tajik, 1,519 (9.2 \%) were Uzbek, 149 (0.9\%) were Kyrgyz and 106 (0.6\%) belong other ethnic origin; International Convention on the Elimination of all Forms of Racial Discrimination, reports submitted by states parties under article 9 of the convention, Addendum, Tajikistan, United Nations, 2011 , p. 18.

54 Of which 94 were Tajik and 1 was Uzbek; International Convention on the Elimination of all Forms of Racial Discrimination, reports submitted by states parties under article 9 of the convention, Addendum, Tajikistan, United Nations, 2011, p. 18.

55 And 4,059 were Tajiks, 244 Uzbeks, 9 Kyrgyz and 39 were from other ethnic origin; International Convention on the Elimination of all Forms of Racial Discrimination, reports submitted by states parties under article 9 of the convention, Addendum, Tajikistan, United Nations, 2011, pp. 18-19.

56 The others were; 632-Tajiks, 70-Uzbek, 5-Kyrgyz and 15 from other ethnic origin; International Convention on the Elimination of all Forms of Racial Discrimination, reports submitted by states parties under article 9 of the convention, Addendum, Tajikistan, United Nations, 2011, p. 19. 
in government departments ${ }^{57}$ where they are 36 out of the total figure of 3,601 and in the local government authorities the Russians employed are 32 out of the total of $6,650 .{ }^{58}$ In the Central Commission on Elections and Referendums there was just 1 Russian out of the total 13 civil servants. ${ }^{59}$ This trend continued to exist in the years to follow as is reflected in the following table.

Table 6. State employees (civil servants) by ethnic origin, as of 1 April 2010

\begin{tabular}{|c|c|c|c|c|c|c|}
\hline$n / n$ & $\begin{array}{l}\text { Total } \\
(\%)\end{array}$ & $\begin{array}{l}\text { Tajik } \\
(\%)\end{array}$ & $\begin{array}{l}\text { Uzbek } \\
(\%)\end{array}$ & $\begin{array}{c}\text { Russian } \\
(\%)\end{array}$ & $\begin{array}{c}\text { Kyrgyz } \\
(\%)\end{array}$ & $\begin{array}{l}\text { Other } \\
(\%)\end{array}$ \\
\hline Tajikistan & $\begin{array}{c}17,496 \\
(100)\end{array}$ & $\begin{array}{l}15,451 \\
(88.3)\end{array}$ & $\begin{array}{l}1,489 \\
(8.5)\end{array}$ & $134(0.7)$ & $196(1.1)$ & $226(1.2)$ \\
\hline $\begin{array}{l}\text { Kühistoni Badakhshon } \\
\text { autonomous province }\end{array}$ & $\begin{array}{c}568 \\
(100)\end{array}$ & $\begin{array}{c}518 \\
(90.2)\end{array}$ & & & $50(8.7)$ & \\
\hline Soghd province & $\begin{array}{r}2,062 \\
(100) \\
\end{array}$ & $\begin{array}{l}1,634 \\
(76.3)\end{array}$ & $\begin{array}{c}415 \\
(19.3)\end{array}$ & $\begin{array}{c}9 \\
(0.4)\end{array}$ & $\begin{array}{c}1 \\
(0.04)\end{array}$ & $3(0.1)$ \\
\hline Khatlon province & $\begin{array}{l}2,406 \\
(100)\end{array}$ & $\begin{array}{l}2,112 \\
(85.2)\end{array}$ & $\begin{array}{c}247 \\
(11.06)\end{array}$ & $\begin{array}{c}14 \\
(0.5)\end{array}$ & & $6(0.2)$ \\
\hline Dushanbe & $\begin{array}{c}307 \\
(100)\end{array}$ & $\begin{array}{l}296 \\
(90.5)\end{array}$ & $\begin{array}{c}9 \\
(2.7)\end{array}$ & $\begin{array}{c}2 \\
(0.6)\end{array}$ & & \\
\hline $\begin{array}{l}\text { Centrally administered } \\
\text { districts }\end{array}$ & $\begin{array}{l}1,411 \\
(100)\end{array}$ & $\begin{array}{l}1230 \\
(85.1)\end{array}$ & $\begin{array}{l}139 \\
(9.6)\end{array}$ & & $\begin{array}{c}41 \\
(2.8)\end{array}$ & $1(0.06)$ \\
\hline Central agencies & $\begin{array}{c}10742 \\
(100)\end{array}$ & $\begin{array}{l}9661 \\
(89.9)\end{array}$ & $\begin{array}{c}652 \\
(6.06)\end{array}$ & $109(1.01)$ & $104(0.96)$ & $\begin{array}{c}216 \\
(2.01)\end{array}$ \\
\hline
\end{tabular}

Compiled on the basis of: International Convention on the Elimination of all Forms of Racial Discrimination, reports submitted by states parties under article 9 of the convention, Addendum, Tajikistan, United Nations, 2011, p. 19.

The representation of minorities including Russians, as reflected above, is in fact because these people are very poorly represented in the population of Tajiks. Not that Russians are only few living in the country but also overwhelming majority of professional and technocrats / bureaucrats have left the country in the process of out-migration. Most of them have very little chance to grab such jobs in the near future because of dominance of the natives living there. Even though the following table is based on 2004 study yet it also reflects the mood among Russians who are willing to go anywhere to earn their living and better standards of education for their children.

Table 7. Are you going to leave Tajikistan for another country? (in \%)

\begin{tabular}{|c|c|c|c|c|c|c|}
\hline Nationality & $\begin{array}{l}\text { In the nearest } \\
\text { future and } \\
\text { forever }\end{array}$ & $\begin{array}{l}\text { I am going, } \\
\text { but later on }\end{array}$ & $\begin{array}{l}\text { would like, but I } \\
\text { don't have } \\
\text { possibility }\end{array}$ & $\begin{array}{l}\text { I want to abroad } \\
\text { for temporarily } \\
\text { earnings }\end{array}$ & No & Other \\
\hline Tajiks & 0.3 & 1.8 & 3.4 & 14.9 & 79.1 & 0.5 \\
\hline Uzbeks & 2.3 & 4.5 & 3.6 & & 79.5 & \\
\hline Russians & 5.0 & 18.8 & 36.6 & 6.9 & 32.7 & \\
\hline Kirghiz & & 18.2 & 13.6 & 13.6 & 54.5 & \\
\hline Turkmen & & & 5.0 & & 95.0 & \\
\hline Tartars & 8.1 & 16.2 & 48.6 & & 27.0 & \\
\hline Others & 3.6 & 21.4 & 32.1 & 5.4 & 35.7 & 1.8 \\
\hline Total & 1.0 & 4.5 & 8.7 & 12.8 & 72.5 & 0.5 \\
\hline
\end{tabular}

Compiled on the basis of: T. N. Bozrikova, "Problems of Ethnic Minorities in Tajikistan", in Sub-regional Seminar on Minority Rights: Cultural Diversity and Development in Central Asia, p. 41.

57 Where the Tajiks contribute 3,099, Uzbeks 277, Kyrgyz 25 and others 20; International Convention on the Elimination of all Forms of Racial Discrimination, reports submitted by states parties under article 9 of the convention, Addendum, Tajikistan, United Nations, 2011, p. 19.

58 Others are; 5,382 Tajiks, 861 Uzbeks, 109 Kyrgyz and 23 from other ethnic origin; International Convention on the Elimination of all Forms of Racial Discrimination, reports submitted by states parties under article 9 of the convention, Addendum, Tajikistan, United Nations, 2011, p. 19.

59 Apart from Russians, the Tajiks were 10 and Uzbeks 2; International Convention on the Elimination of all Forms of Racial Discrimination, reports submitted by states parties under article 9 of the convention, Addendum, Tajikistan, United Nations, 2011, p. 19. 
The main reasons, according to survey are difficult socio-economic conditions (unemployment, low salary, etc.), absence of prospects for children, limited communication in the native language, departing of the friends, relatives host of other causes other causes many of them have shown eagerness to deport to earn better future (As shown in the following Table). Noteworthy however is that majority of Turkic Iranian stock is willing to stay back and confront the situation. Russians on the other hand have shown willingness to move out but since Russian Federation itself discourages permanent settlement of migrants therefore the Tajik Russians do not want to leave the country and accordingly around $70 \%$ of them are forced to face the conditions of the country and elevate themselves in the given scenario. Most of them, more than half of the Tajik Russians in Dushanbe, are pensioners and as such have very little to work. ${ }^{60}$ However it is the new generation of Russians that is worried for future. Despite the legal equality of all citizens, the major problem confronting Russians of Central Asia relates to employment access. ${ }^{61}$

Table 8. Main reasons of departure from Tajikistan (in \%)

\begin{tabular}{|c|c|c|c|c|c|}
\hline Nationality & $\begin{array}{c}\text { Difficult } \\
\text { social } \\
\text { conditions }\end{array}$ & $\begin{array}{c}\text { Absence of } \\
\text { prospects } \\
\text { for children }\end{array}$ & $\begin{array}{c}\text { Limited communication } \\
\text { on the native language, } \\
\text { departing of the friends }\end{array}$ & $\begin{array}{c}\text { Attraction to } \\
\text { the historical } \\
\text { Motherland }\end{array}$ & Other \\
\hline Tajiks & 74.2 & - & & Refused \\
to answer
\end{tabular}

Compiled on the basis of: T. N. Bozrikova, "Problems of Ethnic Minorities in Tajikistan", in Sub-regional Seminar on Minority Rights: Cultural Diversity and Development in Central Asia, p. 41.

The employment of the public offices have accentuated the ethinicisation of the professional ranks to the point that most of the natives work in the state sector and ethnic minorities in the private sector. The Russians find themselves excluded not only from the public offices but also from large companies, that control energy and other critical industries, whether privatized or state controlled. ${ }^{62}$ So in order to secure jobs Russians are in favour of reorientation in employment in the food and light industries, in agriculture, trade, and the services. ${ }^{63}$

The given scenario suggests that Russians have representations in various sectors of the government / owned by government almost to the tune of their population share. This as compared to the past is very insignificant and thus in an overall situation they represent between 0.5 to $0.7 \%$. Tajik government has employed many of them in the border troops soon after the independence. ${ }^{64}$ But since Tajik government has depended mostly on Russian military for the reason of defense soon after independence ${ }^{65}$ has depended on Russian $201^{\text {st }}$ Motorized Rifle Division. ${ }^{66}$

60 Tajikistan began privatizing its state holdings in 1992; Iraj Bashiri, Tajikistan: An Overview; In Tajikistan large scale privatisation has made slow but steady progress in recent years; Emmanuel Maurice (Eds), Law in transition: Central Asia, European Bank for Reconstruction and Development, Japan, 2003, p. 17.

61 Sebastian Peyrouse, Occasional Papers, pp. 13-14.

62 Sebastian Peyrouse, Occasional Papers, p. 14

63 Valerii Aleksandrovich Tishkov, Ethnicity, Nationalism and Conflict in and After the Soviet Union: The Mind Aflame, p. 122.

64 Boris Rumer (Ed), Central Asia in Transition: Dilemmas of Political and Economic development, p. 126.

65 Library of congress - federal research division, country profile Tajikistan, p. 15; In the beginning they were declared neutral, with only focus on safe grading important military and industrial instillations and to act as peace keepers. But with the passage of time they focused on to keep the pro-communist government in power in Dushanbe; Monica Shepherr, "Intervention in Central Asia," Perspective, Vol. VII, No. III, JanuaryFebruary, 1997, available online at http://www.bu.edu/iscip/vol7/Shepherd.html, accessed 01 September 2012.

66 In 1996 Tajikistan housed a total of 16,500 which included 12,500 border troops from $201^{\text {st }}$ Motorized Rifle Division. At present Tajikistan is employing 12,000 troops of Russians Federal Border Guard which also include Tajikistan Enlisted Personal. These 200 Russian families of former border guards are living in the 
Given the scenario Russians, Tartars and representatives of other nationalities have considered that their material status is worse than majority of the population. Even though among the majority about $11.1 \%$ Tajiks estimate their material status as worse than the rest, but $23.8 \%$ Russians, $18.9 \%$ Tartars and $19.6 \%$ other nationalities have indicated that they have lost the gains of the past and accordingly are sufferers. ${ }^{67}$ This is also because there are people who consider that there has not been witnessed any change, as compared to the past, and among them there are 72\% Tajiks, 93.2\% Uzbeks, 61.4\% Russians, 81.8\% Kirghiz, $95 \%$ Turkmen, $67.6 \%$ Tartars and $55.4 \%$ other nationalities. ${ }^{68}$

Thus in presence of these conditions more active and mobile section of the national minorities work in international, local non-governmental organisations and business structures. Because work in these organisations does not require the knowledge of the state language.

Russians thus prefer to invest in private enterprises operating small enterprises that provide jobs in data processing, maintenance, plumbing, electrical work, private security, or are running cafes and boutiques. Many Russians also work in the goods trade between Central Asia and Russia, and some times more remote destinations such as Turkey. ${ }^{69}$

In case of public sector employment the ignorance or poor knowledge of state language is posing them several problems and many times problems get generated because of the poor knowledge of the state language as is found in the expressions below. ${ }^{70}$

"Attitude of my colleagues to me is very good. But I think that my nationality influences on my promotion at workplace and position in society. If I were Tajik, for sure I would be now a chief. I cannot advance beyond of the reached, though I have a lot of knowledge and experience, in comparison to my colleagues. Despite the fact that I have lived in kishlak for a long time and I know Tajik language, to me it is very difficult to write documents in Tajik language and furthermore to learn technical terminology in Tajik» (Luidmila...belongs to a minority group of Tajikistan).

"In our institute Russian language is more and more neglected, all clerical work, educational process is transferred to the state language. There is no literature. The same is for medics. My son is a doctor, they are forced to write sickness histories in Tajik language. What are we going to do? How to work further» (Luibov... belongs to a minority group of Tajikistan).

\section{CONCLUSION}

The present numbers of Russians therefore hardly have any significant representation in various economic sectors of the country. Their fortunes have changed after the fall of USSR and large scale migrations of Russians thereafter has pushed the residual minority to the wall without any hope to review their fortunes.

country. The main reason for their stay in Tajikistan is their inability to obtain the allowances and housing to which they were theoretically entitled upon their return to Russia; Sebastien Peyrouse, Occasional Papers, p. 6;http://www.marines.mil/news/publications/Documents/Kazakstan,\%20Kyrgystan,\%20Tajikistan,\%20Turkme nistan,\%20and\%20Uzbekistan\%20Study_4.pdf, P, 201.

67 T. N. Bozrikova, "Problems of Ethnic Minorities in Tajikistan", in Sub-regional Seminar on Minority Rights: Cultural Diversity and Development in Central Asia, p. 40.

68 T. N. Bozrikova, "Problems of Ethnic Minorities in Tajikistan", in Sub-regional Seminar on Minority Rights: Cultural Diversity and Development in Central Asia, p. 40.

69 Sebastian Peyrouse, Occasional Papers, p. 15.

70 T. N. Bozrikova, "Problems of Ethnic Minorities in Tajikistan", in Sub-regional Seminar on Minority Rights: Cultural Diversity and Development in Central Asia, pp. 29-31. 